AGH Journal of Mining and Geoengineering • Vol. 37 • No. 1 • 2013

http://dx.doi.org/10.7494/mining.2013.37.1.51

Tomasz Marciniszyn*, Adam Sieradzki*, Ryszard Poprawski*

\title{
RESONANCE PHENOMENON IN THE QUARTZITE FROM JEGŁOWA (POLAND)
}

\section{Introduction}

Quartzite is a metamorphic rock [1], which results from the metamorphism process of sandstones and mudstones almost exclusively constructed from fragments of quartz at temperatures greater than $150-200^{\circ} \mathrm{C}$ and pressures of 1500 bars [2]. Quartzite samples come from Jegłowa Mine (50 $43^{\prime} 5^{\prime}$ 'N $17^{\circ} 9^{\prime} 14^{\prime}$ 'E), located on the Strzelin Hills which belong to the foothills of the Sudeten massif (see maps in Figure 1). The Sudeten massif is composed of late-palaeozoic metamorphic rocks such as gneiss, quartzite, quartz schist, homeland schist measures or marble. Quartzite occurring at the Strzelin Hills has been known about since the end of the $19^{\text {th }}$ century [3]. An age of the quartzite is estimated on Low Devonian [3]. The lithological profile for the Jegłowa is presented in Figure 1. Quartzites and quartz schist from the Jegłowa are composed of detrital and authigenic quartz grains and of variable amounts of sericite.

The quartzite schist has a lepiodogranoblastic texture, and the quartzite itself has a granoblastic texsture. The detrital quartz grains mainly occur in the thick bedded quartzites. The smallest amount of detrital quartz is presented in the quartzite schist, mainly composed of authigenic quartz grains. The samples used in our measurements come from the upper layer situated on the quartz schist (Fig. 1).

From a geophysical point of view there are few papers about quartzite. Authors of one paper [4] describe the effect of a shock wave on the crystallographic orientation of quartz crystals in quartzite from the Vredefort impact site in South Africa. Mineralogical, geochemi$\mathrm{cal}$, and isotopic analyses were consistent with the biological origin of the filament-like textures. Detrital quartz in the mats could indicate baffling, trapping, and binding of bacterial communities [5]. The authors of [5] the paper concluded that the wrinkle structures in the Mozaan Group quartzites were fossil microbial mats.

\footnotetext{
* Wroclaw University of Technology, Institute of Physics; tomasz.marciniszyn@pwr.wroc.pl; adam.sieradzki@pwr.wroc.pl; ryszard.poprawski@pwr.wroc.pl
} 

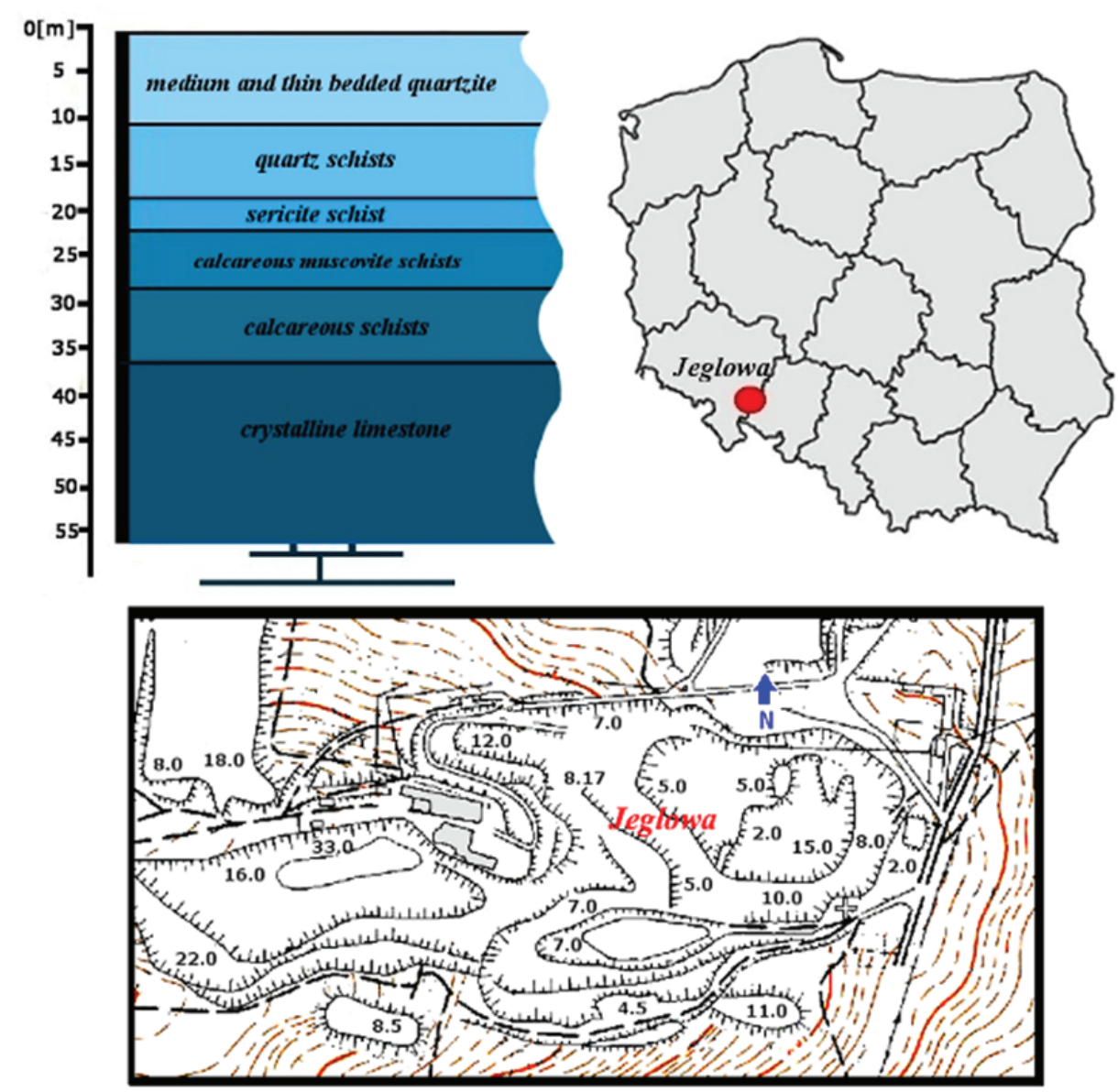

Fig. 1. The lithological profile for the Jegłowa area dependent on the depth. Jegłowa location, point, in the right of the map. The height diagram is at the bottom.

The values mean differences in height levels in meters

Quartzite is a material composed of $\mathrm{SiO}_{2}$ grains in $98 \%$ and $\mathrm{Al}_{2} \mathrm{O}_{3}$ about $1.0 \%$ (see Tab. 1). The great advantage of quartzite, due to $\mathrm{SiO}_{2}$ grains, is its hardness, which is equal to 7 in the Mohs scale. Quartzite is a very good fireproof material with a fire temperatur resistance of $T=1700^{\circ} \mathrm{C}$ [6]. In the $20^{\text {th }}$ century the quartzite was used most frequently to build the 'martenowski' furnaces, i.e. open-hearth furnaces [6]. Now the quartzite is used in the civil engineering industry (stone roofs, stone interior accessories, road paving and other).

The aim of this paper is to demonstrate the results of high-resolution dielectric spectroscopy measurements (more than 830 points per decade) of quartzite rock for which the described method allows for the detection of grains in the rock material in which the resonance phenomenon is observed. 
TABLE 1

Chemical composition of quartzite sample on base of spectral analysis by XRF

\begin{tabular}{|c|c|c|}
\hline Compound & $\begin{array}{c}\text { Before heating, } \\
{[\%]}\end{array}$ & $\begin{array}{c}\text { After heating at } \mathbf{1 0 0 0}^{\circ} \mathbf{C}, \\
{[\%]}\end{array}$ \\
\hline $\mathrm{SiO}_{2}$ & 98.7 & 98.6 \\
\hline $\mathrm{Al}_{2} \mathrm{O}_{3}$ & 0.71 & 0.72 \\
\hline $\mathrm{Fe}_{2} \mathrm{O}_{3}$ & 0.05 & 0.03 \\
\hline $\mathrm{CaO}$ & $<0.01$ & 0.01 \\
\hline $\mathrm{MgO}$ & $<0.01$ & 0.01 \\
\hline $\mathrm{Cr}_{2} \mathrm{O}_{3}$ & $<0.01$ & $<0.01$ \\
\hline $\mathrm{MnO}$ & $<0.01$ & $<0.01$ \\
\hline $\mathrm{K}_{2} \mathrm{O}$ & 0.19 & 0.18 \\
\hline $\mathrm{P}_{2} \mathrm{O}_{5}$ & $<0.01$ & $<0.01$ \\
\hline $\mathrm{SO}_{3}$ & $<0.01$ & $<0.01$ \\
\hline $\mathrm{Na}_{2} \mathrm{O}$ & $<0.01$ & $<0.01$ \\
\hline $\mathrm{TiO}_{2}$ & 0.03 & 0.03 \\
\hline $\mathrm{ZrO}_{2}$ & $<0.01$ & $<0.01$ \\
\hline
\end{tabular}

\section{Experimental}

Rectangular plates with an identical area of $9 \times 25 \mathrm{~mm}$, but different thicknesses of $7.15 \mathrm{~mm}, 5.18 \mathrm{~mm}$ and $2.4 \mathrm{~mm}$, were cut from the quartzite block. The measurements were performed for the samples without annealing and after annealing in order to determine the influence of the thermal treatment on the dielectrical properties and the microstructure. The annealing processes were performed at $800^{\circ} \mathrm{C}, 900^{\circ} \mathrm{C}$ or $1000^{\circ} \mathrm{C}$ in a stabilized conventional box furnace. The chemical composition which depends on the annealing temperature was determined using the XRF technique. Samples were mechanically polished and air-dried for dielectrical measurements. A silver paste was used for improving the dielectrical contacts. The dielectric spectroscopy measurements were performed using an automatic Novocontrol Alpha impedance analyzer at frequency range from $10^{2}$ to $3 \cdot 10^{7} \mathrm{~Hz}$. Measurements of complex dielectric permittivity were performed in a vacuum at a temperature range of $50-330 \mathrm{~K}$ with a stable temperature of $0.5 \mathrm{~K}$.

\subsection{Basic dielectric measurements}

The complex dielectric permittivity over wide frequency and temperature ranges were measured for quartzite samples. The real part of permittivity as a result of frequency for the selected temperatures is presented in Figure 2a. As can be seen in Figure 2a, at about 
$1.5 \cdot 10^{7} \mathrm{~Hz}$ the permittivity rapidly increases. It is observed that in a frequency range $10^{2}-10^{6}[\mathrm{~Hz}]$ the real part of the permittivity is almost constant. The inset in Figure 2a shows the maximum of the real part of the permittivity $\varepsilon_{\text {max }}^{\prime}(f)$. In Figure $2 b$ the loss tangent, $\operatorname{tg} \delta(f)$, is presented as a function of frequencies for several temperatures. The character of the $\operatorname{tg} \delta(f)$ plot is typical for a system revealing a piezoelectric behavior [7].

Quartzite contains practically $99 \%$ of quartz which is well known as a piezoelectric crystal. The resonance in quartz occurs in $\mathrm{MHz}$ range and depends of the strain [8, 9]. Based on this observation, we concluded that resonance which occurs in quartzite rock is caused by the quartz vibrations.

We have also summarized that the resonance in quartzite is caused by the piezoelectric vibrations of quartz grains contained in the studied material.

a)

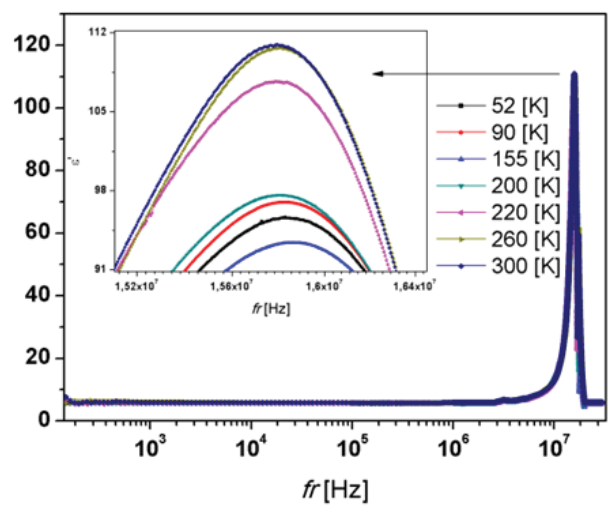

b)

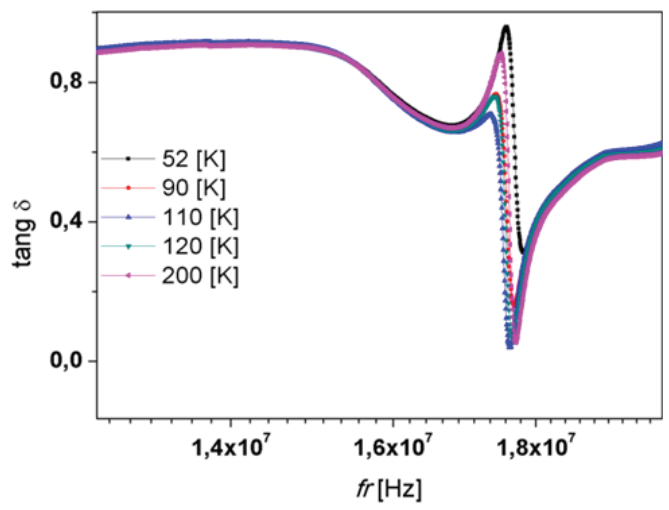

Fig. 2. The frequency dependence of the real part of the dielectric permittivity (a) and the loss tangent (b) for selected temperatures

\subsection{Influence of the thickness on the piezoelectric resonance}

The measurements of the complex dielectric permittivity of the quartzite samples with three different thicknesses, i.e. $2.42 \cdot 10^{-3} \mathrm{~m}, 5.18 \cdot 10^{-3} \mathrm{~m} 7.15 \cdot 10^{-3} \mathrm{~m}$, over a wide range of frequencies and temperatures were carried out in order to determine the influence of different thickness on the piezoelectric properties. At a constant temperature in the majority of the investigated frequencies (from $10^{2} \mathrm{~Hz}$ up to about $10 \mathrm{MHz}$ ) the real dielectric permittivity had a constant value, for example at $1 \mathrm{kHz}$ the real part equals 8 for each thickness. The dependence on real dielectric permittivity for the three thicknesses of the quartzite samples as a function of frequency with significant changes occurring for selected temperatures is presented in Figure 3. The double peak in Figure $3\left(f_{m 1}\right.$ and $\left.f_{m 2}\right)$ is well observed for each thickness of the sample. It can be caused by the occurrence of two average grains size in the quartzite. 

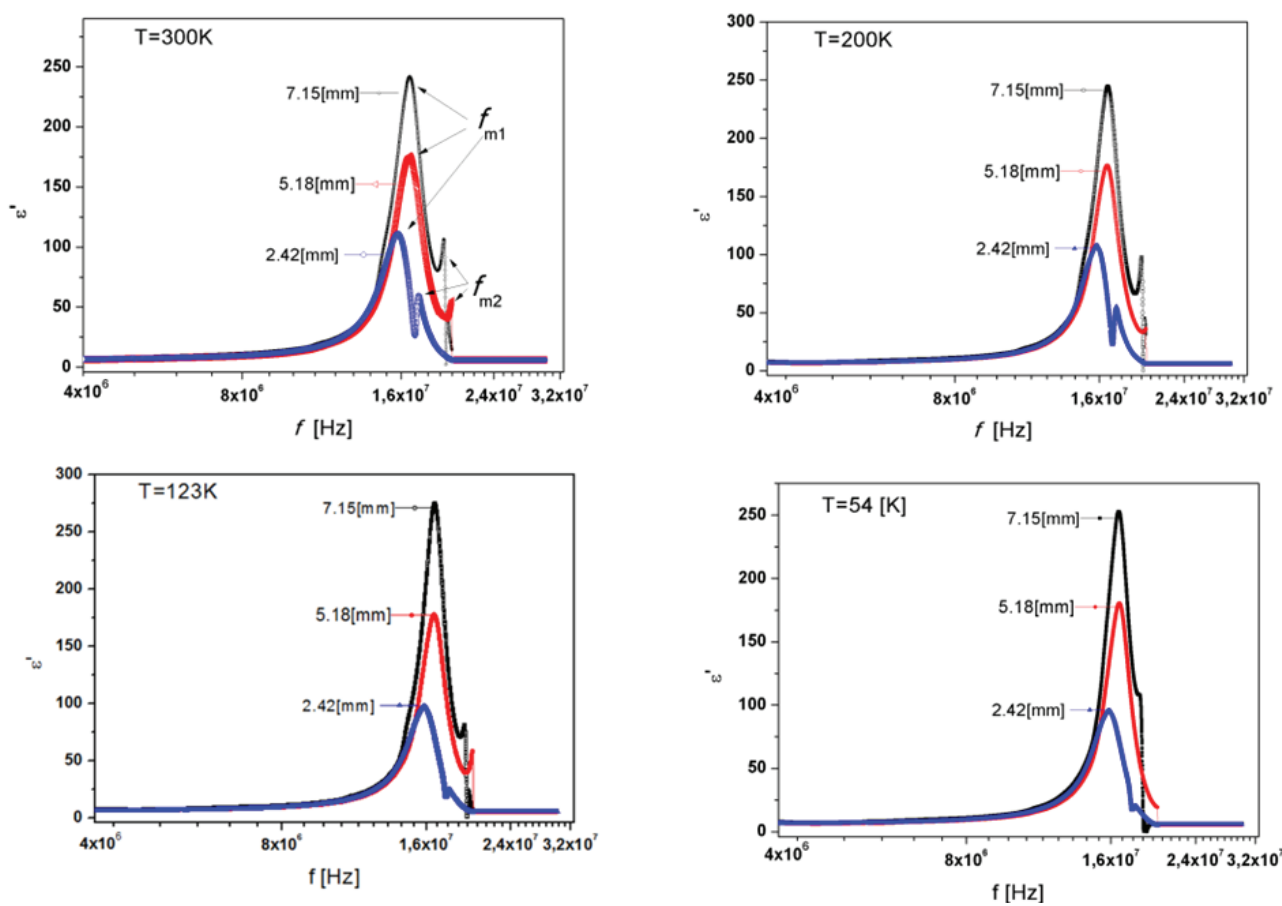

Fig. 3. The real part of the dielectric permittivity as a function of frequency for quartzite samples with three thicknesses $\left(7.15 \cdot 1^{-3} \mathrm{~m}, 5.18 \cdot 10^{-3} \mathrm{~m}\right.$ and $\left.2.42 \cdot 10^{-3} \mathrm{~m}\right)$ for selected temperatures.

The $f_{m 1}$ and $f_{m 2}$ means the resonances frequencies

\subsection{Influence of annealing on the properties of quartzite}

The spectral analysis of the chemical composition were performed with XRF for notannealed quartzite and that annealed at $1000^{\circ} \mathrm{C}$. Comparing the results before and after the annealing, any significant changes of the chemical composition were not noticeable. The quartzite samples consist of about $98.7 \% \quad \mathrm{SiO}_{2}$ and $0.71 \% \quad \mathrm{Al}_{2} \mathrm{O}_{3}$ before and after the annealing (see Tab. 1).

A photo of quartzite from Jegłowa before and after the annealing at $1000^{\circ} \mathrm{C}$ is presented in Figure 4. It is clear to see that annealing leads to a colour change from gray to almond white. A magnification of the images by ten times (Fig. $4 \mathrm{c}, \mathrm{d}$ ) shows that after annealing at $1000^{\circ} \mathrm{C}$ the evident crystallites are formed.

The real part of the dielectric permittivity $\varepsilon$ ' versus frequency before and after the annealing at $800^{\circ} \mathrm{C}, 900^{\circ} \mathrm{C}$ and $1000^{\circ} \mathrm{C}$ is presented in Figure 5, respectively. In Figure 5 it's clearly visible that the resonant frequency, $f_{m 1}$, is still evident in the next steps of the sample annealing. Another fact worth noting regards the peak corresponding to the resonance frequency $f_{m 2}$, which disappears with the increasing annealing temperature up to $1000^{\circ} \mathrm{C}$. Based on this information and taking into consideration that after annealing at $1000^{\circ} \mathrm{C}$ agglomerates are formed on the surface of quartzite (see Fig. 4), it can be concluded that the resonant peak 
$f_{m 2}$ is caused by the quartz grains found near the surface area and the peak resonant oscillation $f_{m 1}$ is caused by the quartz grains localized from the interior of the studied material.

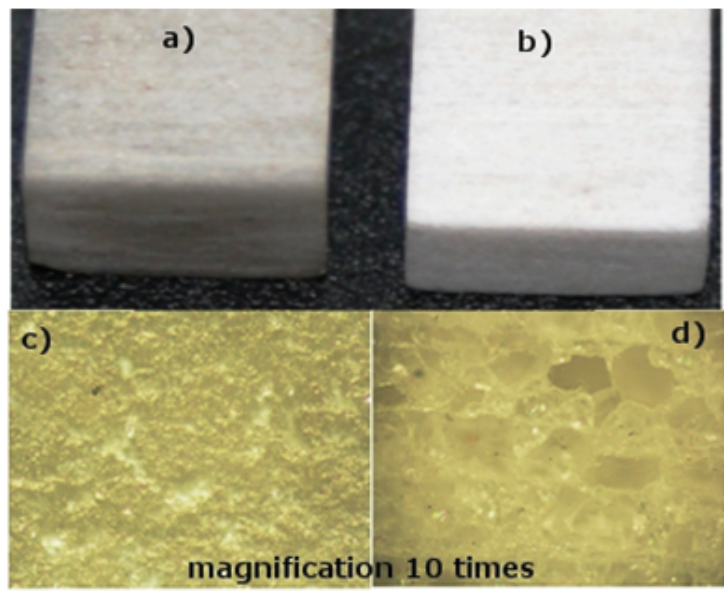

Fig. 4. Pictures of the quartzite before $(a, c)$ and after $(b, d)$ heating at $1000^{\circ} \mathrm{C} ;(\mathrm{c}, \mathrm{d}) 10$-time magnification

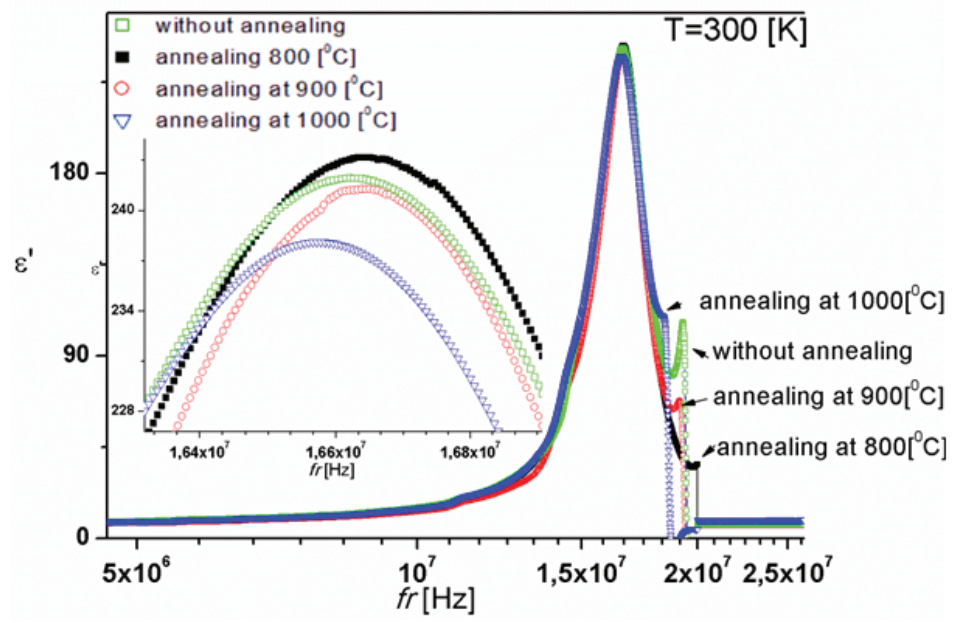

Fig. 5. The real part of the permittivity as a function of frequency for the quartzite samples before and after annealing at $800^{\circ} \mathrm{C}, 900^{\circ} \mathrm{C}$ and $1000^{\circ} \mathrm{C}$. The temperature of the measured was $300 \mathrm{~K}$

After annealing at $900^{\circ} \mathrm{C}$ the maximum of $\varepsilon^{\prime}(f)$ evidently increases, which is probably caused by the $\mathrm{SiO}_{2}$ structure change. In the annealing process at $900^{\circ} \mathrm{C}$ the sample changes its structure from $\alpha$-quartz into tridymite $\beta$, which in the cooling process passes to $\beta$-trydymit, then to $\gamma$-trydymit. Low-temperature quartz $\alpha$ belongs to the trigonal system, while trydymit crystallizes in the hexagonal system [6]. 


\subsection{The grain size determination from the high-resolution dielectric spectroscopy measurements}

One of the most popular rock measurement methods is dielectrical resistivity. This method is divided into a two-electrode method and four-electrode method [10]. Knowing the value of dielectrical resistance, the type, porosity, permeability and water content of a rock can be determined [11]. A measurement method which allows for the detection and determination of the size of vibrating particles is an important supplement for the available the dielectrical resistivity methods currently used for the rock testing.

In the rock studied, the quartz grains vibration under the eclectic field caused the propagation of the elastic wave. Resonant oscillations depend of the thickness, chemical composition and the material density [12]. The resonant frequency of the elastic wave propagated in the material along the direction perpendicular to the sample thickness, fulfills the basic physical equation $[13,14]$ :

$$
f=\frac{1}{2 d} \sqrt{\frac{E}{\rho}}
$$

where, $E$ is the Young modulus of the material, $\rho$ is the material density and the size of the sample is $d$.

Using Young's modulus, the density of the studied material and its resonant frequency was determined from dielectric measurements, and based on the formula, the size $(d)$ of the particles (grains) in the material could be determined.

Three samples with different thicknesses were studied in order to show independent results using the method. As shown with quartzite, resonant frequency does not depend on temperature (Fig. 2), therefore resonant frequency data $\left(f_{m 1}, f_{m 2}\right)$ for each sample at a temperature of $300 \mathrm{~K}$ (Fig. 3a) was used in the calculations.

Based on the equation and taking $E=72 \mathrm{GPa}$ (the value for quartz, because quartzite samples consist of about $98.7 \% \mathrm{SiO}_{2}$ ), the density of quartzite $\rho=2650 \mathrm{~kg} / \mathrm{m}^{3}$ the average size of the grains $\left(d_{f m 1}, d_{f m 2}\right)$ were calculated (see Tab. 2).

\section{TABLE 2}

The grain size $\left(d_{f m 1}, d_{f m 2}\right)$ depending of the resonant frequency $\left(f_{m 1}, f_{m 2}\right)$ and sample thickness $d$

\begin{tabular}{|c|c|c|c|c|}
\hline $\begin{array}{c}\text { Sample thinness } \boldsymbol{d}, \\
{\left[\mathbf{m} \cdot \mathbf{1 0}^{-3}\right]}\end{array}$ & $\begin{array}{c}\text { Resonant frequency } \boldsymbol{f}_{\boldsymbol{m} \mathbf{1}}, \\
{[\mathbf{m h z}]}\end{array}$ & $\begin{array}{c}\text { Grain size } \\
\boldsymbol{d}_{\boldsymbol{f} \boldsymbol{m} \mathbf{1}},[\mathbf{m m}]\end{array}$ & $\begin{array}{c}\text { Resonant frequency } \\
\boldsymbol{f}_{\boldsymbol{m} \mathbf{2}},[\mathbf{m h z}]\end{array}$ & $\begin{array}{c}\text { Grain size } \\
\boldsymbol{d}_{\boldsymbol{f m} \mathbf{2}},[\mathbf{m m}]\end{array}$ \\
\hline 2.42 & $15.78 \pm 0.01$ & $1.57 \pm 0.01$ & $19.29 \pm 0.01$ & $1.36 \pm 0.01$ \\
\hline 5.18 & $16.60 \pm 0.01$ & $1.62 \pm 0.01$ & $19.99 \pm 0.01$ & $1.32 \pm 0.02$ \\
\hline 7.15 & $16.62 \pm 0.01$ & $1.66 \pm 0.02$ & $17.27 \pm 0.01$ & $1.51 \pm 0.01$ \\
\hline
\end{tabular}

Based on the Table 2, it can be observed that the grain size calculated for the $f_{m 1}$ and for $f_{m 2}$ depending on the sample thickness does not show any significant differences. This observation is justified, because a quartzite sample independent of the thickness contains grains about similar average size distribution. Results depending on the thickness can therefore be calculated for the resonant frequency and, $f_{m 1}$ and $f_{m 2}$ were averaged for thickness, and the 
results were estimated at $d_{f m 1}=0.16 \pm 0.01 \mathrm{~mm}$ and $d_{f m 2}=0.14 \pm 0.01 \mathrm{~mm}$. It should be noted that the piezoelectric resonance in the quartzite is caused by vibrations occurring inside the $\mathrm{SiO}_{2}$ grains with average size of $0.16 \mathrm{~mm}$ and $0.14 \mathrm{~mm}$.

\section{Conclusions}

The measurement results for the real part of permittivity and $\operatorname{tg} \delta$ demonstrate a resonance at about $20 \mathrm{MHz}$ which is caused by the vibrations occurring inside the $\mathrm{SiO}_{2}$ grains.

The method presented is based on high resolution dielectric spectroscopy which allows for the detection and calculation of the size of quartz grains in the material. The average size of quartz grains contained in quartzite equals $0.16 \mathrm{~mm}$ and $0.14 \mathrm{~mm}$ for non-annealed quartzite and $0.1568 \mathrm{~mm}$ for quartzite annealed above $800^{\circ} \mathrm{C}$.

It was observed that in real part of permittivity was constant in wide temperature and frequency ranges, and almost twice as high as that for quartz crystals [15]. It was concluded that resonance did not depend on the annealing process. Another point worth noting is the fact that the chemical composition was almost the same before and after annealing. The sample after annealing at $1000^{\circ} \mathrm{C}$ changed colour from gray to almost white. Magnified images of the quartzite surface showed that crystallites were formed after $1000^{\circ} \mathrm{C}$ heating processes.

\section{Acknowledgments}

This work is co-financed by the European Union as part of the European Social Fund.

\section{REFERENCES}

[1] Powell D.: Quartzite. Mineral Information Institute, 2009

[2] Blatt H., Tracy R.J.: Petrology, Igneous, Sedimentary, and Metamorphic. $2^{\text {nd }}$ edition, 1996, p. 355

[3] Chmura K.: Lithology of the quartzite series. Kraków 1967

[4] Wenk H.-R., Lonardelli I., Vogel S.C., Tullis J.: South Africa Dauphiné twinning as evidence for an impact origin of preferred orientation in in quartzite: An example from Vredefort, South Africa. Geology, vol. 33, 2005, pp. 273-276

[5] Noffke N., Hazen R., Nhleko N.: Earth's earliest microbial mats in a siliciclastic marine environment (2.9 Ga Mozaan Group, South Africa). Geology, vol. 31, 2005, pp. 673-676

[6] Piech J.: Wyłożenia ogniotrwałe pieców i urządzeń cieplnych. Kraków, 1999

[7] Kłos A., Pajączkowska A., Pawlaczyk C., Markiewicz E.: On growth and dielectric properties of Ca $\mathrm{GdO}_{4}\left(\mathrm{BO}_{3}\right)_{3}$ single crystals. Proc. SPIE, vol. 4412, 2001, pp. 369-374

[8] Geennwood C.J.: Etched silicon vibration sensor. J.Phys. E.: Sci. Instrum. vol. 17, 1984, pp. 650-652 Jonscher, A., K., 1983, Dielectric Relaxation in Solids (Chelsea, London: Dielectrics Press)

[9] Smits J.G., Tilmans H.A.C., Hoen K., Mulder M., Van Vuuren J., Boom G.: Resonant diaphragm pressure measurements system $\mathrm{ZnO}$ on Si excitation. Sensor and Actuators, vol. 4, 1983, pp. 565-571

[10] Rust C.F., Petroleum M.: Electrical Resistivity Measurements on Reservoir Rock Samples by the Two-Electrode and Four-Electrode. Society of Petroleum Engineers, 1952, pp. 217-224

[11] Kahraman S., Fener M.: Electrical resistivity measurements to predict abrasion resistance of rock aggregates. Mater. Sci., vol. 31, no. 2, 2008, pp. 179-184

[12] Sauerbrey G.Z.: Use of quartz vibration for weighing thin films on a microbalance. J. Physik, vol. 155, 1959, pp. 206-212

[13] Yound D.H., Freedman A.R.:. University Physics with modern physics, 2000, p. 607

[14] Benes E., Groschl M., Bruger W., Schmid M.: Sensor based on piezoelectric resonators. Sensors and Actuators A, 1995, pp. 1-21

[15] Krupka J., Derzakowski K., Tobar M., Hartnett J., Geyerk R.: Complex permittivity of some ultralow loss dielectric crystals at cryogenic temperatures. Meas. Sci. Technol., vol. 10, 1999, pp. 387-392 